\title{
Antimicrobial Susceptibility, Heavy Metals Tolerance and Plasmid Curing of Shigella Species Isolated from El- Dakahlia, Egypt
}

\author{
Gamal M. EL-Sherbiny*, Shehata M. E. \\ Botany and Microbiology Department, Faculty of Science, Al- Azhar University, Cairo, Egypt \\ *Corresponding author: gamalelsherbiny1970@yahoo.com
}

Received October 20, 2014; Revised November 10, 2014; Accepted November 18, 2014

\begin{abstract}
The aim of this study was carried out determine the antibiotic susceptibility, heavy metals tolerance and plasmid curing of Shigella species isolating from diarrheal stool samples were collected from different hospitals in El- Dakahlia and Nile River waters, Egypt, from January 2012 to August 2014. After characterization and identification the results obtained show that 172 isolates isolated from stool samples belong to four Shigella species (Shigella sonnei $48.25 \%$, Shigella flexneri $29.65 \%$, Shigella dysenteriae $13.95 \%$ and Shigella boydii 8.13 $\%$ ) while 5 isolates isolated from Nile River water were found belong to (Shigella sonnei $40 \%$, Shigella dysenteriae $40 \%$ and Shigella flexneri $20 \%$ ).The antibiotics susceptibility of Shigella sp. to11 antibiotics revealed that the most potent antibiotics were found co-amoxyclav, ciprofloxacin and ceftriaxone respectively while penicillin, ampicillin, co-trimoxazole and chloramphenicol respectively give low activity. The tolerance of Shigella sp. to heavy metals, (cadmium, nickel cobalt and zinc) revealed that all isolates sensitive to 1 and $0.1 \mathrm{M}$ concentration. Plasmid profile analysis of ten isolates Shigella sonnei shown that this isolates having numerous plasmid ranged from 8.5 to $4.3 \mathrm{~kb}$. Treat isolates with SDS $2 \%$ for 24 hours to plasmid curing after recovery subject to antibiotic sensitivity and heavy metals tolerance. In conclusion, Shigella-associated diarrhea remains relatively common in Egypt and can be used ciprofloxacin and ceftriaxone for treat Shigella sp. infection. The heavy metal tolerance of Shigella sp .associated with resistance to antibiotics ampicillin, tetracycline and chloramphenicol. Present Shigella sp. in Nile River waters indicates polluted with sewage waters and becomes sources of some epidemic diseases.
\end{abstract}

Keywords: Shigella species, antibiotics susceptibility, heavy metals tolerance and plasmid curing

Cite This Article: Gamal M. EL-Sherbiny, and Shehata M. E., "Antimicrobial Susceptibility, Heavy Metals Tolerance and Plasmid Curing of Shigella Species Isolated from El- Dakahlia, Egypt." American Journal of Microbiological Research, vol. 2, no. 6 (2014): 211-216. doi: 10.12691/ajmr-2-6-7.

\section{Introduction}

Shigella spp. is a virulent bacterium of Enterobacteriaceae family. Shigellosis is an acute gastroenteritis caused by shigellae, including Shigella dysenteriae, Shigella flexneri, Shigella boydii and Shigella sonnei. Shigellosis remains a public-health problem in most developing countries where communities are ravaged by poverty, war, poor sanitation, personal hygiene, and water supplies [1]. Epidemiologic reports show that about 140 million people suffer from shigellosis with estimated 600,000 deaths per year worldwide [2,3]. A major food-borne threat to public health in many developed countries where the issues of sanitation are concerned $[4,5,6]$. S. sonnei is spread mainly by means of fecal-oral transmission. Other possible modes of transmission can be from ingestion of contaminated food or water and subcutaneous contact with inanimate objects. $S$. sonnei infectivity dose is very low, as few as 100-200 bacteria are needed to cause a clinical infection, Shigellosis $[7,8]$. The emergence of antimicrobial resistance within members of the Enterobacteriaceae family is posing serious problems in the treatment of outbreaks of infections. Since its first report in studies conducted in the 1950s, multiple-drug resistance transmitted by plasmids among Shigella species has been reported from many countries $[9,10]$. Moreover, an increase in resistance against many different drugs has been observed in the last two decades. In India, over 70\% of Shigella isolates were resistant to two or more drugs including ampicillin and co-trimoxazole during 2002 to 2007 [11]. Reports from Indonesia [12], Bangladesh [13], Malaysia [14] and Nepal [15] show increasing prevalence of Shigella isolates with multiple resistance to ampicillin, trimethoprim-sulphamethoxazole, tetracycline, and nalidixic acid. Similar resistance profiles have been also reported from Africa [16] Central America [17], Europe [18] and South America [19]. The genetic determinants that confer resistance to antibiotics are mostly located on plasmids (known as R-plasmids). These extra-chromosomal DNA sequences are often transferable to other bacteria in the environment and can be responsible for the emergence of resistance to multiple antibiotics [20]. The use of plasmid- 
curing agents in combination with antibiotics may serve as a possible way to contain the development and spread of antibiotic resistance encoded by antibiotic resistant Rplasmids. This work was aimed to study the evaluation incidence of Shigella sp. resistant to antibiotics and heavy metals having plasmids in hospital and Nile River waters and curing plasmid.

\section{Materials and Methods}

Three hundred forty five stool samples used in this study were collected from patients having vomiting and diarrhea symptoms in hospitals El- Dakahlia, Egypt, and twenty water samples collected from Nile River waters at different sites from period between January 2012 to August 2014. The samples collected processed by standard microbiological methods and cultivated on MacConkey agar, Salmonella-Shigella agar and deoxycholate citrate agar. All media were readily prepared (Oxfoid, England).

\subsection{Assessment and Purification of Bacterial Isolates}

The plates containing of MacConkey agar, SalmonellaShigella agar and deoxycholate citrate agar media were inoculation with samples collected and incubated at $37^{\circ} \mathrm{C}$ for 24 and 48 hrs. respectively. The grown colonies were selected, picked up and transferred to agar slants containing the same medium. The purified isolated were subjected to a scheme of experimental identification.

\subsection{Bacterial Identification}

The pure culture was identify based on morphology, physiology and biochemical tests Microbiological Methods $6^{\text {th }}$ [21], Bergey's Manual of Determinative Bacteriology [22] and confirmed by the slide agglutination test using polyvalent and monovalent antisera (Denka Seiken, Japan).

\subsection{Antibiotic Susceptibility Testing}

Susceptibility to antibiotics was assessed using the Kirby-Bauer disc diffusion technique while results were read following the Clinical Laboratory Standards Institute's guidelines National Committee for Clinical Laboratory Standards 2010 [23]. The panel of antibiotics used included: ampicillin $(10 \mu \mathrm{g})$, penicillin $(10 \mu \mathrm{g})$, chloramphenicol (30 $\mu \mathrm{g})$, co-amoxyclav $(20 / 10 \mu \mathrm{g})$, aztreonam $(30 \mu \mathrm{g})$, trimethoprim /sulphamethoxazole (cotrimoxazole, $1.25 / 23.75 \mu \mathrm{g})$, ceftriaxone $(30 \mu \mathrm{g})$ nalidixic acid $(30 \mu \mathrm{g})$, tetracycline $(30 \mu \mathrm{g})$, streptomycin $(30 \mu \mathrm{g})$ and ciprofloxacin $(5 \mu \mathrm{g})$ The suspension of the test organism in nutrient broth was matched with $0.5 \mathrm{McF}$ arland turbidity standards to give a concentration of $1.5 \times 10^{8} \mathrm{CFU} / \mathrm{ml}$, while the inoculated plates were incubated at $35^{\circ} \mathrm{C}$ for $18-24$ hours. The degree of susceptibility of the test isolates to each antibiotic was determined on basis inhibition zone diameter. Multidrug resistance was defined in this study as resistance to three or more antibiotics tested. All antibiotic discs were purchased from Oxoid. UK.

\subsection{Tolerance of Heavy Metals by Using Agar Dilution Method}

All isolates were also tested to determine tolerance to four heavy metals including (cobalt, cadmium, nickel and zinc) was carried out by using agar dilution method modified by Narasimhulu et al., 2010 [24]. Prepare Mueller-Hinton agar media and approximate concentration molar (M) $1 \mathrm{M}, 0.1 \mathrm{M}, 0.01 \mathrm{M}$ and 0.001 for each heavy metals, added to flask contained $50 \mathrm{ml}$ Mueller-Hinton, mixed well, and autoclaved at $121^{\circ} \mathrm{C}$ for 15 minutes. After autoclaving, inoculating by refreshed growth Shigella isolates and incubated at $37^{\circ} \mathrm{C}$ for $24 \mathrm{hrs}$. growth, meaning resistance and if there is no growth meaning sensitive.

\subsection{Plasmid Isolation}

Overnight Shigella $(10 \mathrm{ml})$ culture was used for the plasmid isolation. After isolation and purification the bands were visualized in $0.7 \%$ agarose gels with 0.5 $\mathrm{mg} / \mathrm{ml}$ of ethidium bromide in $10 \mathrm{mM}$ Tris-acetate buffer The procedure was conducted according to the method described by (Anderson D.G. and McKay 1983) and Frere $1994[25,26]$.

\subsection{Plasmid Curing}

Shigella sp. isolates high resistant antibiotics and heavy metals subjected to plasmid curing. The plasmid curing was done by exposing the overnight grown culture at $\left(37^{\circ} \mathrm{C}\right)$ and $2 \%$ Sodium Dodecyl Sulphate (SDS) [25,27]. After plasmid curing the Shigella isolates subjected to antibiotic sensitivity and heavy metals tolerance.

\section{Results}

One hundred seventy two Shigella isolates isolated from 345 stool samples and five Shigella isolates isolated from 20 water samples. This isolates subject to scheme for characterization and identification according to morphological physiology and biochemical tests and confirmed by the slide agglutination test using polyvalent and monovalent antisera (Denka Seiken, Japan). From identification results, the isolates isolating from stool samples were found belong to Shigella species as the following (83 isolates Shigella sonnei $48.25 \%, 51$ isolates Shigella flexneri $29.65 \%, 24$ isolates Shigella dysenteriae $13.95 \%$ and 14 isolates Shigella boydii 8.13\%) while 4 isolates isolated from water samples belong to 2 isolates Shigella sonnei, 2 isolates Shigella dysenteriae and 1 isolates Shigella flexneri Table 1.

Table 1. Ratio of Shigella isolated from stool and water samples

\begin{tabular}{|l|c|c|}
\hline \multirow{2}{*}{ Bacterial species } & \multicolumn{2}{|c|}{ Prevalence } \\
\cline { 2 - 3 } & stool & water \\
\hline Shigella sonnei & $83(48.25 \%)$ & $2(40 \%)$ \\
\hline Shigella flexneri & $51(29.65 \%)$ & $2(40 \%)$ \\
\hline Shigella dysenteriae & $24(13.95 \%)$ & $1(20 \%)$ \\
\hline Shigella boydii & $14(8.13 \%)$ & 0.0 \\
\hline
\end{tabular}

The susceptibility of Shigella sp.isolates to 11 antibiotics, the results obtained showed that the most potent antibiotic against those isolates co-amoxyclav, ciprofloxacin and ceftriaxone while penicillin, ampicillin, 
co-trimoxazole, chloramphenicol and tetracycline respectively give low activity and high resistant ratio against isolates. In generally Shigella sp. isolated from stool samples more resistant to antibiotics tested from than Shigella sp. isolated from Nile River waters Table 2 and Table 3. In present study, the effects of four heavy metals on Shigella sp. isolates were investigated with different molar concentration, from heavy metals (cadmium, nickel, cobalt and zinc). Results obtained revealed that all isolates were sensitive to four heavy metals at concentration land $0.1 \mathrm{M}$ but resistant at concentration $0.01 \mathrm{M}$ Table 4 and Table 5. The plasmid profile analysis shown that Shigella sonnei. have numerous plasmid ranged from $8.5-4.3 \mathrm{~kb}$ Figure 1. This isolates subject to plasmid curing with SDS $2 \%$ for 24 hours after recovery subject to antibiotic sensitivity and tolerance heavy metals comparing between results before and after plasmid curing, showed change on antibiotics sensitivity and tolerance of heavy metals.

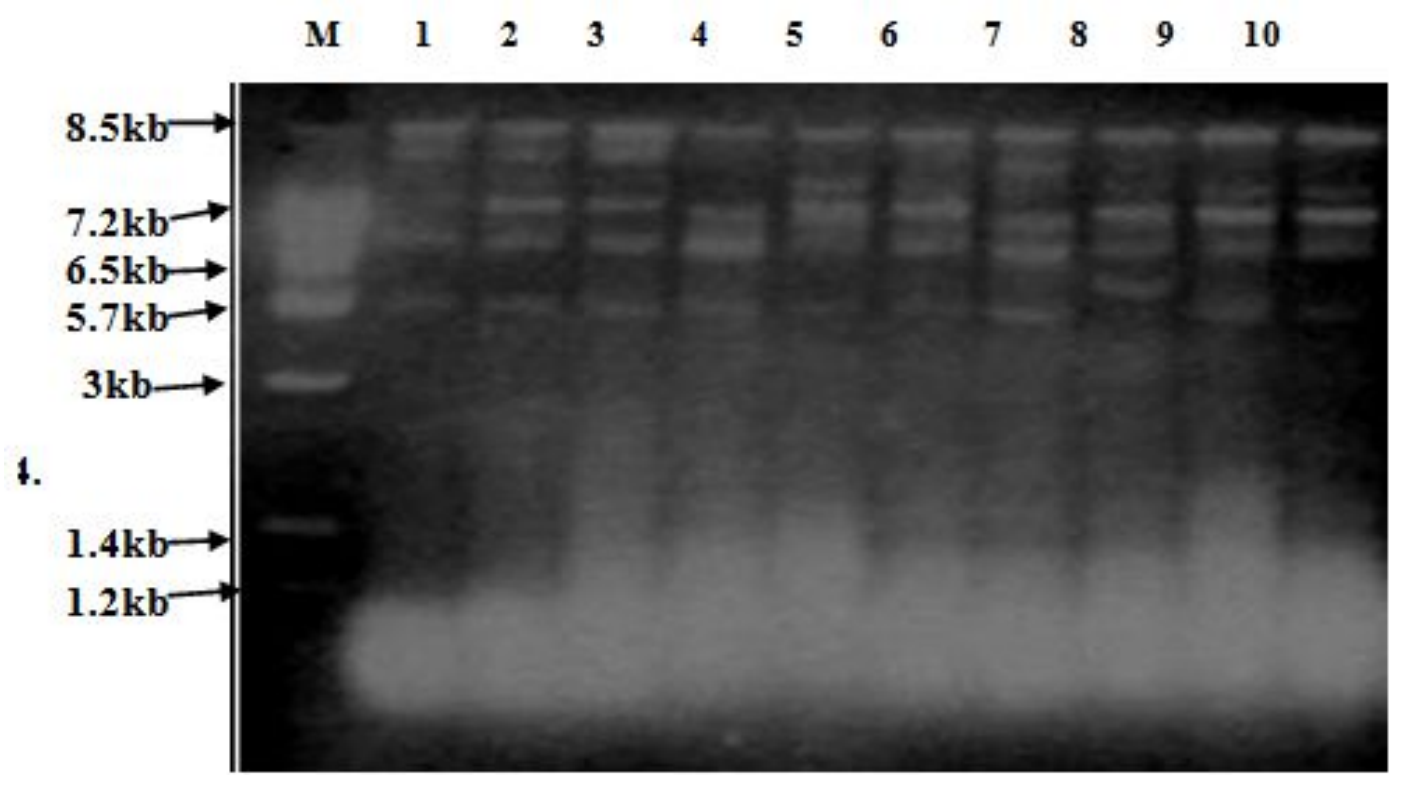

Figure 1. Visualization of plasmids in an agarose gel $(0.7 \%)$. Lane M represents marker from lane 1 to lane 10 plasmids isolated from Shigella sonnei resistance to antibiotic and heavy metals tolerances

Table 2. Percentage resistance of Shigella sp. isolated from stool samples antibiotics before and after plasmid curing

\begin{tabular}{|l|c|c|c|c|c|c|c|c|}
\hline \multirow{2}{*}{ Antibiotics } & \multicolumn{2}{|c}{ S. sonnei } & \multicolumn{2}{c|}{ S. flexneri } & \multicolumn{2}{c|}{ S. dysenteriae } & \multicolumn{2}{c|}{ S. boydii } \\
\cline { 2 - 10 } & before (\%) & after (\%) & before (\%) & after (\%) & before (\%) & after (\%) & before (\%) & after (\%) \\
\hline Ampicillin & 67.2 & 50.4 & 75.52 & 58.8 & 74.99 & 20.83 & 72.42 & 28.52 \\
\hline Penicillin & 74.4 & 51.6 & 80.36 & 56.84 & 79.16 & 50.0 & 78.56 & 35.71 \\
\hline Streptomycin & 28.8 & 20.4 & 29.4 & 23.52 & 29.16 & 8.33 & 28.57 & 14.28 \\
\hline Tetracycline & 49.2 & 38.4 & 60.76 & 43.12 & 54.16 & 25.0 & 50.0 & 28.57 \\
\hline Chloramphenicol & 56.4 & 45.6 & 66.64 & 49.0 & 58.33 & 25.0 & 42.85 & 21.42 \\
\hline Co-trimoxazole & 68.4 & 39.6 & 76.44 & 54.88 & 58.33 & 41.66 & 57.13 & 28.52 \\
\hline Nalidixic Acid & 19.2 & 14.4 & 17.64 & 0.0 & 16.66 & 4.166 & 35.71 & 21.42 \\
\hline Ceftriaxone & 3.6 & 0.0 & 9.8 & 3.92 & 4.16 & 0.0 & 14.28 & 0.0 \\
\hline Co-amoxyclav & 0.0 & 0.0 & 0.0 & 0.0 & 0.0 & 0.0 & 0.0 & 0.0 \\
\hline Aztreonam & 24.0 & 15.5 & 27.44 & 15.68 & 20.83 & 8.33 & 14.28 & 0.0 \\
\hline Ciprofloxacin & 0.0 & 0.0 & 0.0 & 0.0 & 4.16 & 0.0 & 0.0 & 0.0 \\
\hline
\end{tabular}

Table 3. Percentage resistance of Shigella sp. isolated from Nile river to antibiotics before and after plasmid curing

\begin{tabular}{|c|c|c|c|c|c|c|}
\hline \multirow[b]{2}{*}{ Antibiotics } & \multicolumn{2}{|c|}{ S. sonnei } & \multicolumn{2}{|c|}{ S. flexneri } & \multicolumn{2}{|c|}{ S. dysenteriae } \\
\hline & before (\%) & after (\%) & before (\%) & after (\%) & before (\%) & after (\%) \\
\hline Ampicillin & 100 & 50 & 100 & 0.0 & 100 & 0.0 \\
\hline Penicillin & 100 & 50 & 100 & 0.0 & 100 & 0.0 \\
\hline Streptomycin & 50 & 0.0 & 50 & 0.0 & 0.0 & 0.0 \\
\hline Tetracycline & 100 & 0.0 & 50 & 0.0 & 100 & 0.0 \\
\hline Chloramphenicol & 50. & 0.0 & 100 & 0.0 & 0.0 & 0.0 \\
\hline Co-trimoxazole & 50 & 0.0 & 50 & 0.0 & 0.0 & 0.0 \\
\hline Nalidixic Acid & 50 & 0.0 & 50 & 0.0 & 0.0 & 0.0 \\
\hline Ceftriaxone & 50 & 0.0 & 50 & 0.0 & 0.0 & 0.0 \\
\hline Co-amoxyclav & 0.0 & 0.0 & 0.0 & 0.0 & 0.0 & 0.0 \\
\hline Aztreonam & 50 & 0.0 & 50 & 0.0 & 100 & 0.0 \\
\hline Ciprofloxacin & 0.0 & 0.0 & 00 & 0.0 & 0.0 & 0.0 \\
\hline
\end{tabular}


Table 4. Tolerance of Shigella sp. isolated from stool samples to heavy metals before plasmid curing

\begin{tabular}{|c|c|c|c|c|c|c|c|c|c|c|c|c|}
\hline \multirow{2}{*}{$\underbrace{\text { Metals conc.(M) }}_{\text {Isolates }}$} & \multicolumn{3}{|c|}{ Cobalt } & \multicolumn{3}{|c|}{ Zinc } & \multicolumn{3}{|c|}{ Nickel } & \multicolumn{3}{|c|}{ Cadmium } \\
\hline & 1 & 0.1 & 0.01 & 1 & 0.1 & 0.01 & 1 & 0.1 & 0.01 & 1 & 0.1 & 0.01 \\
\hline S. sonnei & $\mathbf{0}$ & $\mathbf{0}$ & $\mathbf{R}$ & $\mathbf{0}$ & 0 & $\mathbf{R}$ & $\mathbf{0}$ & $\mathbf{0}$ & $\mathbf{R}$ & $\mathbf{0}$ & $\mathbf{0}$ & $\mathbf{R}$ \\
\hline S. flexneri & $\mathbf{0}$ & 0 & $\mathbf{R}$ & $\mathbf{0}$ & 0 & $\mathbf{R}$ & 0 & $\mathbf{0}$ & $\mathbf{R}$ & $\mathbf{0}$ & 0 & $\mathbf{R}$ \\
\hline S. dysenteriae & $\mathbf{0}$ & $\mathbf{0}$ & $\mathbf{R}$ & $\mathbf{0}$ & 0 & $\mathbf{R}$ & $\mathbf{0}$ & 0 & $\mathbf{R}$ & $\mathbf{0}$ & $\mathbf{0}$ & $\mathbf{R}$ \\
\hline S. boydii & $\mathbf{0}$ & $\mathbf{0}$ & $\mathbf{R}$ & $\mathbf{0}$ & $\mathbf{0}$ & $\mathbf{R}$ & $\mathbf{0}$ & $\mathbf{0}$ & $\mathbf{R}$ & $\mathbf{0}$ & $\mathbf{0}$ & $\mathbf{R}$ \\
\hline
\end{tabular}

$\mathrm{R}=$ resistant, $0=$ no growth or sensitive

Table 5. Tolerance of Shigella sp. isolated from Nile river to heavy metals before plasmid curing

\begin{tabular}{|c|c|c|c|c|c|c|c|c|c|c|c|c|}
\hline \multirow{2}{*}{$\underbrace{\text { Metals conc.(M) }}_{\text {Isolates }}$} & \multicolumn{3}{|c|}{ Cobalt } & \multicolumn{3}{|c|}{ Zinc } & \multicolumn{3}{|c|}{ Nickel } & \multicolumn{3}{|c|}{ Cadmium } \\
\hline & 1 & 0.1 & 0.01 & 1 & 0.1 & 0.01 & 1 & 0.1 & 0.01 & 1 & 0.1 & 0.01 \\
\hline S. sonnei & $\mathbf{0}$ & $\mathbf{0}$ & $\mathbf{R}$ & $\mathbf{0}$ & $\mathbf{0}$ & $\mathbf{R}$ & 0 & 0 & $\mathbf{R}$ & 0 & $\mathbf{0}$ & $\mathbf{R}$ \\
\hline S. flexneri & $\mathbf{0}$ & $\mathbf{0}$ & $\mathbf{R}$ & $\mathbf{0}$ & $\mathbf{0}$ & $\mathbf{R}$ & $\mathbf{0}$ & $\mathbf{0}$ & $\mathbf{R}$ & 0 & $\mathbf{0}$ & $\mathbf{R}$ \\
\hline S. dysenteriae & $\mathbf{0}$ & 0 & $\mathbf{R}$ & $\mathbf{0}$ & $\mathbf{0}$ & $\mathbf{R}$ & $\mathbf{0}$ & $\mathbf{0}$ & $\mathbf{R}$ & 0 & $\mathbf{0}$ & $\mathbf{R}$ \\
\hline
\end{tabular}

$\mathrm{R}=$ resistant, $0=$ no growth or sensitive.

\begin{tabular}{|c|c|c|c|c|c|c|c|c|c|c|c|c|c|c|c|c|}
\hline \multirow{2}{*}{$\underbrace{\text { Metals conc.(M) }}_{\text {Isolates }}$} & \multicolumn{4}{|c|}{ Cobalt } & \multicolumn{4}{|c|}{ Zinc } & \multicolumn{4}{|c|}{ Nickel } & \multicolumn{4}{|c|}{ Cadmium } \\
\hline & 1 & 0.1 & 0.01 & 0.001 & 1 & 0.1 & 0.01 & 0.001 & 1 & 0.1 & 0.01 & 0.001 & 1 & 0.1 & 0.01 & 0.001 \\
\hline S. sonnei & $\mathbf{0}$ & $\mathbf{0}$ & $\mathbf{0}$ & $\mathbf{R}$ & $\mathbf{0}$ & $\mathbf{0}$ & $\mathbf{0}$ & $\mathbf{R}$ & $\mathbf{0}$ & $\mathbf{0}$ & $\mathbf{0}$ & $\mathbf{R}$ & $\mathbf{0}$ & $\mathbf{0}$ & $\mathbf{0}$ & $\mathbf{R}$ \\
\hline S. flexneri & $\mathbf{0}$ & $\mathbf{0}$ & $\mathbf{0}$ & $\mathbf{R}$ & $\mathbf{0}$ & $\mathbf{0}$ & $\mathbf{0}$ & $\mathbf{R}$ & $\mathbf{0}$ & $\mathbf{0}$ & $\mathbf{0}$ & $\mathbf{R}$ & $\mathbf{0}$ & 0 & $\mathbf{0}$ & $\mathbf{R}$ \\
\hline S. dysenteriae & $\mathbf{0}$ & $\mathbf{0}$ & $\mathbf{0}$ & $\mathbf{R}$ & $\mathbf{0}$ & $\mathbf{0}$ & $\mathbf{0}$ & $\mathbf{R}$ & $\mathbf{0}$ & $\mathbf{0}$ & $\mathbf{0}$ & $\mathbf{R}$ & 0 & 0 & $\mathbf{0}$ & $\mathbf{R}$ \\
\hline S. boydii & $\mathbf{0}$ & 0 & $\mathbf{0}$ & $\mathbf{R}$ & 0 & 0 & $\mathbf{0}$ & $\mathbf{R}$ & 0 & 0 & $\mathbf{0}$ & $\mathbf{R}$ & $\mathbf{0}$ & 0 & $\mathbf{0}$ & $\mathbf{R}$ \\
\hline
\end{tabular}

$\mathrm{R}=$ resistant, $0=$ no growth or sensitive.

Table 7. Tolerance of Shigella sp. isolated from Nile River to heavy metals after plasmid curing

\begin{tabular}{|l|c|c|c|c|c|c|c|c|c|c|c|c|c|c|c|c|c|c|}
\hline \multirow{2}{*}{\begin{tabular}{|c|c|c|c|c|c|c|c|c|c|c|} 
Cotals conc.(M) \\
Isolates
\end{tabular}} & $\mathbf{1}$ & $\mathbf{0 . 1}$ & $\mathbf{0 . 0 1}$ & $\mathbf{0 . 0 0 1}$ & $\mathbf{1}$ & $\mathbf{0 . 1}$ & $\mathbf{0 . 0 1}$ & $\mathbf{0 . 0 0 1}$ & $\mathbf{1}$ & $\mathbf{0 . 1}$ & $\mathbf{0 . 0 1}$ & $\mathbf{0 . 0 0 1}$ & $\mathbf{1}$ & $\mathbf{0 . 1}$ & $\mathbf{0 . 0 1}$ & $\mathbf{0 . 0 0 1}$ \\
\hline S. sonnei & $\mathbf{0}$ & $\mathbf{0}$ & $\mathbf{0}$ & $\mathbf{R}$ & $\mathbf{0}$ & $\mathbf{0}$ & $\mathbf{0}$ & $\mathbf{R}$ & $\mathbf{0}$ & $\mathbf{0}$ & $\mathbf{0}$ & $\mathbf{R}$ & $\mathbf{0}$ & $\mathbf{0}$ & $\mathbf{0}$ & $\mathbf{R}$ \\
\hline S. flexneri & $\mathbf{0}$ & $\mathbf{0}$ & $\mathbf{0}$ & $\mathbf{R}$ & $\mathbf{0}$ & $\mathbf{0}$ & $\mathbf{0}$ & $\mathbf{R}$ & $\mathbf{0}$ & $\mathbf{0}$ & $\mathbf{0}$ & $\mathbf{R}$ & $\mathbf{0}$ & $\mathbf{0}$ & $\mathbf{0}$ & $\mathbf{R}$ \\
\hline S. dysenteriae & $\mathbf{0}$ & $\mathbf{0}$ & $\mathbf{0}$ & $\mathbf{R}$ & $\mathbf{0}$ & $\mathbf{0}$ & $\mathbf{0}$ & $\mathbf{R}$ & $\mathbf{0}$ & $\mathbf{0}$ & $\mathbf{0}$ & $\mathbf{R}$ & $\mathbf{0}$ & $\mathbf{0}$ & $\mathbf{0}$ & $\mathbf{R}$ \\
\hline
\end{tabular}

$\mathrm{R}=$ resistant, $0=$ no growth or sensitive

\section{Discussion}

Shigellosis accounts for a significant proportion of morbidity and mortality, especially in developing countries [28,29]. Four species of the genus Shigella, $S$. sonnei S. flexneri. S. dysenteriae, S. boydii, cause a wide spectrum of illnesses ranging from watery diarrhea to fulminant dysentery [30,31,32]. The frequency of occurrence of Shigella sp. differs by country and in different populations within a country [30,33]. The samples used in this study were collected from patients having vomiting and diarrhea symptoms in hospitals ElDakahlia, Egypt, and water samples collected from Nile River waters at different sites from period between January 2012 to August 2014. According to result obtained from isolation and identification were found the predominant isolate $S$. sonnei with a mean prevalence of $48.25 \%$, followed by $S$. flexneri $29.65 \%$, S. dysenteriae $13.95 \%$ and $S$. boydii $8.13 \%$ from total isolates, while isolates isolated from Nile River waters samples was found as the following, S. sonnei represented $40 \%, S$. dysenteriae $40 \%$ and S. flexneri $20 \%$ from total isolates. The results obtained of this study shows change in the pattern of species isolated in Egypt by Remon et al., 2004 [34]. S. flexneri is dominant to isolate in developing countries such as Bangladesh, Pakistan, Indonesia, India, some countries in Africa, and Iran $[35,36]$ while S. sonnei is the major Shigella isolate in developed countries.[35]. Shawky and Saleh 2007 isolating Shigella sp. from Nile River Damietta branch and Ahmed et al., 2013 isolated 46 isolates S. flexneri from Egypt [37,38]. In this prospective, community-based study, we were able to demonstrate that Shigella was an important cause of diarrhea in patients the Nile River Delta of Egypt. The antibiotics susceptibility revealed that most potent activity against all Shigella isolates co-amoxyclav, ciprofloxacin and ceftriaxone. These findings were in agreement with reports of other studies indicating Shigella isolates are sensitive to these antibiotics $[28,39,40,41,42]$. While penicillin, ampicillin, co-trimoxazole, chloramphenicol and tetracycline respectively give low activity and high resistant ratio against isolates. In this study was demonstrated a high level of antimicrobial resistance in Shigella species isolated from this samples. The multidrug resistant isolates represented incidence especially the emergence of resistance to streptomycin indicates that designing a surveillance system for antimicrobial resistance in Egypt and the introduction of integrated guidelines for the appropriate use of antibiotics are urgently needed. In present study, the effects of four heavy metals on Shigella sp. isolates were investigated with different molar concentration, the heavy metals were used cadmium, nickel, cobalt and zinc. Results obtained revealed that all isolates were sensitive to four heavy metals at concentration $1 \mathrm{M}$ and.0.1 Finally all isolates resistance to 
four heavy metals at concentration $0.01 \mathrm{M}$. The interpretation of these results may be due to the fact that Shigella sp. have many mechanisms for heavy metals resistance. Detoxifying mechanisms developed by resistant microorganisms such as complexation by exopolysaccharides, binding with bacterial cell envelopes, metal reduction, metal efflux etc. These mechanisms are sometime encoded in plasmid genes facilitating the transfer of toxic metal resistance from one cell to another [43]. Prasad et al., 2009, found that all isolates were sensitive to heavy metals $(\mathrm{Cd} 2+, \mathrm{Ag}+, \mathrm{Ar} 2+, \mathrm{Co} 2+, \mathrm{Ni} 2+$, $\mathrm{Hg} 2+$, and $\mathrm{Pb} 2+$ ) at concentration $0.1 \mathrm{M}$, and most of them were resistant to heavy metals at concentration $(0.0001 \mathrm{M})$ [44]. The interaction between heavy metals and antibiotic resistance are of three types: heavy metals interaction with antibiotic compounds, heavy metals interaction with antibiotic resistance genes or even their products and heavy metal interaction with bacterial properties like conjugation. Nishino et al., 2007 of cations heavy metals complex with antibiotics [45]. The heavy metal tolerance associated with resistance to antibiotics such as ampicillin, tetracycline, chloramphenicol, erythromycin, kanamycin and streptomycin[46] The plasmid profile analysis demonstrated the virulence plasmid ranged from (8.5 to $4.3 \mathrm{~kb}$ ). This plasmid was not used for pattern comparison of isolates because of its documented instability on subculture $[47,48]$. Most the Shigella sonnei. isolates were found to harbour a more one and similar plasmid. In the study, numerous plasmid patterns were found in each of the Shigella species. Tacket et. al. 1984 also found multiple plasmid profiles in all Shigella species [49]. Litwin et al.1991 studied 74 Shigella sp. they found plasmid patterns for each species were distinct [50]. It was found this study there were relation between plasmid bands and multiple antibiotic resistant pattern and heavy metals tolerance. Curing of plasmids was carried out with SDS, sub culture plasmid curing was achieved by growing the strains, treatment with SDS $2 \%$. The plasmid elimination was accompanied by drastic changes in antibiotic resistance and morphology of the colonies [51]. Some isolates lose resistant to penicillin, ampicillin, cotrimoxazole, tetracycline and chloramphenicol when treated SDS and increase inhibition zone diameter. With comparison between results before and after plasmid curing, showed change on antibiotics resistant and tolerance of heavy metals. The loss of antibiotic and heavy metals resistance was concomitant with the loss of plasmid content so that the results showed that some cured isolates had lost their antibiotic and heavy metals resistance. This indicates that the resistance determinants of tested antibiotics were located on plasmids.

\section{Conclusion}

In conclusion, Shigella sonnei is predominating isolates on diarrhea stool samples isolated from ElDakahlia, Hospital Egypt. Although some of Shigella isolates multidrug resistance but can be used ciprofloxcin for treatment Shigella sp. Infection. The heavy metal tolerance associated with resistance to antibiotics such as ampicillin, tetracycline and chloramphenicol. The Present Shigella sp. in Nile River waters this indicated that is polluted with sewage water and represented incidence on healthy people and distribution of epidemic diseases. Therefore need to additional control to prevent spread, include antibiotics development with some plasmid curing agent and integrated guidelines for the appropriate use of antibiotics are urgently needed.

\section{References}

[1] Shears P. Shigella infections. Ann Trop Med Parasitol 1996, 90(2) $105-11$.

[2] Vaccine research and development: new strategies for accelerating Shigella vaccine development. Wkly Epidemiol Rec 1997, 72: 7379 .

[3] World Health Organization. Diarrheal disease due to Shigella disease. In: Vaccines, immunization and biological. Geneva: World Health Organization; 1998, 1-5.

[4] Thomas L.H. and Gerald T.K. Baron's Medical Microbiology. In: Shigella, 4th edn. 2000, 389-400.

[5] Niyogi S.K. Shigellosis. J Microbiol. 2005, 43: 33-143.

[6] Sansonetti P.J. Shigellosis: an old disease in new clothes.2006, PLoS Med. 3: 354.

[7] Shiferaw B., Shallow S., Marcus R., Segler S., Soderlund D, Hardnett F.P. and Van Gilder T Trends in population-based active surveillance for shigellosis and demographic variability in Food Net sites, 1996-1999. Clinical Infectious Diseases. 2004, 38: 175-180.

[8] Stothard P., Van Domselaar G., Shrivastava S., Guo A., O'Neill B., Cruz J., Ellison M. and Wishart D.S. BacMap an interactive picture atlas of annotated bacterial genomes. Nucleic Acids Res. 2005, 33: D317-D320.

[9] Geo FB, Janet SB, Stepehn AM,. Jawetz, Melnick and Adelberg's. Medical Microbiology, 1998. 21st ed. Appleton \& Lange publishers, 224-226.

[10] Brito A and Nij B. Antibiotic resistance pattern and plasmid 8 . profiles for Shigella spp. isolated in Cordoba, Argentina. J. Antimicrob Chemother 1994, 34: 253-259.

[11] Srinivasa H., Baijayanti M., Raksha Y. Magnitude of drug resistant shigellosis: A report from Bangalore. Indian Journal of Medical Microbiology. 2009, 27: 358-360.

[12] Subekti D, Oyofo BA, Tjaniadi P, Corwin AL, Larasati 10. W, Putri $\mathrm{M}$ et al. Shigella spp. surveillance in Indonesia: the emergence or reemergence of S. dysenteriae. Emerg Infect Dis. 2001, 7: 137-140.

[13] Shahid NS, Rahaman MM, Haider K, Banu H, Rahman N. Changing pattern of resistant Shiga bacillus (Shigella dysenteriae type 1) and Shigella flexneri in Bangladesh. J. Infect Dis. 1985, 152: 1114-119.

[14] Thong KL, Hoe CH, Koh YT, Yasim RM. Prevalence 12. of multidrug-resistant Shigella isolated in Malaysia. J. Health Popul Nutr. 2002, 20: 356-8.

[15] Khan S., Priti S., Mukhtar A., Ashish A., Wilson G and Easow JM, Isolation of Shigella species and their resistance patterns to a panel of fifteen antibiotics in mid and far western region of Nepal. Asian Pac J. Trop Dis. 2014, 4(1): 30-34

[16] Bogaerts J, Verhaegen J, Munyabikali JP, Mukantabana B, Lemmens P, Vandeven J. Antimicrobial resistance and serotypes of Shigella isolates in Kigali, Rwanda (1983 to 1993): increased frequency of multiple resistance. Diagn Microbiol Infect Dis. 1997 28: $165-171$.

[17] Mata LJ, Gangarosa EJ Cáceres A, Perera DR, Mejicanos. ML. Epidemic Shiga bacillus dysentery in Central America. Etiologic investigations in Guatemala, 1969. J. Infect Dis. 1970, 122: 170180.

[18] Essers B, Burnens AP, Lanfranchini FM, Somaruga SG, 16. von Vigier RO, Schaad UB et al. Acute community-acquired diarrhea requiring hospital admission in Swiss children. Clin Infect Dis. 2000, 31: 192-196.

[19] Torres ME, Pírez MC, Schelotto F, Varela G, Parodi 17. V, Allende $\mathrm{F}$ et al. Etiology of children's diarrhea in Montevideo, Uruguay: associated pathogens and unusual isolates. J. Clin Microbiol. 2001, 39: 2134-219.

[20] Schelz Z, Molnar J and Hohmann J. Antimicrobial and antiplasmid activities of essential oils. Fitoterapia.2006, 77: 27985. 
[21] Collins HC, Lyne MP and Grange MJ. Microbiological Methods: $6^{\text {th }}$ ed. Agency London. 200. 1989.

[22] Holt Jk, Krieg NR, Sneath PH, Staley JT and Williams ST. Bergey's Manual of Determinative Bacteriology $9^{\text {th }}$. Baltimore. 1994.

[23] Clinical and Laboratory Standards Institute. Performance standard for antimicrobial susceptibility testing. Approved standard M100S20-30(1). NationalCommittee for Clinical Laboratory Standards, 2010, Wayne, PA. USA.

[24] Narasimhulu K., Sreenivasa R.P.S. and Vinod A.V. Isolation and identification of bacterial strains and study of their resistance to heavy metals and antibiotics. J. Microbial Biochem. Technol. 2010, 2: 074-076.

[25] Anderson D.G. and McKay L.L. Simple and rapid method for isolating large plasmid DNA from lactic streptococci. Appl. Environ. Microbiol., 1983, 46: 549-552.

[26] Frere J. Simple method for extracting plasmid DNA from lactic acid bacteria. Lett. Appl. Microbiol. 1994, 18: 227-229.

[27] Durve A., Naphade S., Bhot M., Varghese J. and Chandra N. Plasmid curing and protein profiling of heavy metal tolerating bacterial isolates. Archives of Applied Science Research. 2013, 5(4): 46-54.

[28] Bhattacharya S, Khanal B, Bhattarai NR and Das ML. Prevalence of Shigella species and their antimicrobial resistance patterns in Eastern Nepal. J. Health Popul Nutr, 2005, 23(4): 339-42.

[29] Kotloff KL, Winickoff JP, Ivanoff B, Clemens JD, Swerdlow DL, Sansonetti PJ, et al. Global burden of Shigella infections: implications for vaccine development and implementation of control strategies. Bull World Health Organ 1999, 77(8): 651-66.

[30] Vrints M, Mairiaux E, Van ME, Collard JM and Bertrand S. Surveillance of antibiotic susceptibility patterns among Shigella sonnei strains isolated in Belgium during the 18-year period 1990 to 2007. J. Clin Microbiol 2009, 47(5): 1379-85

[31] Al-Moyed KA, Harmal NS, Al-Harasy AH and AlShamahy HA. Increasing single and multi-antibiotic resistance in Shigella species isolated from shigellosis patients in Sana'a, Yemen. Saudi Med J. 2006, 27(8): 1157-60.

[32] Mamatha B, Pusapati BR and Rituparna C. Changing patterns of antimicrobial susceptibility of Shigella serotypes isolated from children with acute diarrhea in Manipal, South India, a 5 year study. Southeast Asian J. Trop Med Public Health 2007, 38(5): 863-6.

[33] Mates A, Eyny D and Philo S. Antimicrobial resistance trends in Shigella serogroups isolated in Israel,1990-1995. Eur J. Clin. Microbiol. Infect. Dis. 2000, 19(2): 08-11

[34] Remon R., Abu-ELYazeed, Thomas F., Wierzb A., Robert W., Frenck, Shannon D. et al., Epidemiology of Shigella associated diarrhea in rural Egyptian children. Am. J. Trop. Med. Hyg. 2004, 71(3), 367-372

[35] Herwana E, Surjawidjaja JE, Salim OC, Indriani N, Bukitwetan P, Lesmana M. Shigella-associated diarrhea in children in South Jakarta, Indonesia. Southeast Asian J. Trop Med Public Health. 2010, 41(2): 418-25.
[36] MoezArdalan K, Zali MR, Dallal MM, Hemami MR and Salmanzadeh-Ahrabi S. Prevalence and pattern of antimicrobial resistance of Shigella species among patients with acute diarrhoea in Karaj, Tehran, Iran. J. Health Popul Nutr. 2003, 21(2): 96-102.

[37] Shawky Z. S. and Saleh A. Revaluation of the microbial of the quality of the Nile River waters at Damietta branch Egypt. Egypt. J. of Aquatic. Res.. 2007, 33 1, 301-311

[38] Ahmed S. F., John K., Tupur H., Jesse M., Amel N. and Momtaz $\mathrm{O}$ W. Genetic characterization of antimicrobial resistance of Shigella flexneri 1c isolates from patients in Egypt and Pakistan. Annals of Clinical Microbiology and Antimicrobials 2013, 12:9

[39] Mengistu G., Gebru M., Tsehaynesh L. and Abraham A. Prevalence and Antimicrobial Susceptibility Patterns of Salmonella serovars and Shigella species Microbial Biochem Technol. 2014, 2.

[40] Yismaw G, Negeri C and Kassu A. A five-year antimicrobial resistance pattern observed in Shigella species isolated from stool samples in Gondar University Hospital, northwest Ethiopia. Ethiop. J. Health Dev 2006, 20(3): 194-8.

[41] Roma B, Worku ST., Mariam S and Langeland N. Antimicrobial susceptibility pattern of Shigella isolates in Awassa. Ethiop J. Health Dev. 2014, 14(2): 149-54.

[42] Jesudason MV. Shigella isolation in Vellore, south India (19972001). Indian J Med Res 2002, 115: 11-3.

[43] Silver S. Bacterial resistances to toxic metal ions-a review. Gene. 1996, 179: 9-19.

[44] Prasad.V. S., Mamatha Ballal, and. Shivananda, P. G action of heavy metals on Pseudomonas aeruginosa strains isolated from infection wound. Journal of Chinese clinical medicine. 2009, 4(3).

[45] Nishino K., Nikaido E. and Yamaguchi A. Regulation of multidrug efflux systems involved in multidrug and metal resistance of Salmonella enteric serovar Typhimurium. Journal of Bacteriology. 2007, 189: 9066-9075.

[46] Raafat M. J. And Alaa H. A. Heavy metals resistant bacteria. AV. Akadmikererlag GmbH, Co, KG, Germany 2013, 24-25.

[47] Sansonetti P.J., Kopecko D.J. and Formal S.B. Shigella sonnei plasmids: Evidence that a large plasmid is necessary for virulence. Infect. Immun., 1981, 34: 75-83. PMCID: PMC350823

[48] Shafik M.H., Al-Quattan H.Y. and. Mohamed M.T. Fulminating Shigella encephalopathy (Ekiri syndrome): A case report. Kuwait Med. J. 2007, 39: 369-372.

[49] Tacket C.O, Shahid N, Huq M.I, Alim A.R and.Cohen. M.L. Usefulness of plasmid profiles for differentiation of Shigella isolates in Bangladesh. J.Clin. Microbiol., 1984, 20: 300-301. PMCID: PMC271311.

[50] Litwin C.M., Storm A.L., Chipowsky S. and Ryan, K.J. Molecular epidemiology of shigella infections: Plasmid profiles, serotype correlation and restriction endonuclease analysis. J. Clin.Microbiol., 1991. 29: 104-108.

[51] Raja S.B, Murali M.R, Malathi G.K, Anbarasu K.and. Devaraj S.N. Effect of aqueous extract of Aegle marmelos fruit on adherence and $\beta$-lactam resistance of Enteropathogenic Escherichia coli by down regulating outer membrane protein C. Am. J. Infect. Dis. 2009, 5: 154-162. 